\title{
ANALISA TEMPERATUR YANG TIMBUL PADA SPROKET DAN RANTAI SEPEDA MOTOR SAAT SEDANG DIJALANKAN YANG BERPENGARUH TERHADAP KEMULURAN RANTAI DENGAN MENGGUNAKAN PROGRAM NISA HEAT
}

\author{
RIKI CANDRA PUTRA \\ Program Studi Teknik Mesin, Fakultas Teknik, Universitas Muhammadiyah Tangerang \\ Jl. Perintis Kemerdekaan I/33 Cikokol-Tangerang \\ Email: riki.candra@gmail.com
}

\begin{abstract}
ABSTRAK
Rantai dan sproket adalah sistem transmisi yang digunakan untuk mentransmisikan daya dan putaran dari penggerak menuju poros yang digerakkan. Rantai dan sproket sepeda motor pada umumnya mengalami kerusakan karena kurangnya perawatan dan pemeliharaan secara baik dan benar. Kerusakan yang terjadi pada umumnya disebabkan oleh gesekan yang terjadi antara gigi sproket dan rantai yang saling bergerak dengan cepat, dari gesekan yang terjadi tersebut menghasilkan panas pada bahan logam rantai dan sproket. Panas yang dihasilkan tersebut sangat mempengaruhi kinerja material. Oleh karena itu perlu diketahui analisa perpindahan panas yang terjadi pada pergesekan antara rantai dan sproket. Penelitian dilaksanakan di berbagai tempat dan di luar ruangan atau di jalan raya, saat sepeda motor melaju pada kecepatan normal dan kemudian berhenti untuk melakukan pengukuran temperatur pada permukaan roda gigi dan sproket. Kondisi cuaca pada saat pengukuran dilakukan pada saat cuaca sedang cerah atau tidak sedang hujan, tujuannya untuk memudahkan pengukuran apabila dalam kondisi kering atau tidak basah karena air dan dianalisa dengan menggunakan software NISA-HEAT untuk melihat distribusi temperatur pada kecepatankecepatan tertentu dan suhu lingkungan yang tertentu, oleh karena itu percobaan ini dapat mewakili putaran roda sepeda motor pada kondisi saat sedang dijalankan dan saat kecepatan sepeda motor yang berubah-ubah. Panas yang didapat pada kondisi temperatur lingkungan yang paling panas yaitu $38^{\circ} \mathrm{C}$ didapat besar temperatur pada sprocket sebesar $52.3^{\circ} \mathrm{C}$ pada kecepatan sepeda motor 70 $\mathrm{km} / \mathrm{jam}$ dengan besar perpindahan panas yang terjadi sebesar 0.543 Watt. Dan dengan bertambahnya kecepatan sepeda motor diatas $70 \mathrm{~km} / \mathrm{jam}$ maka temperatur sproket menjadi semakin bertambah dengan temperatur lingkungan yang sama.
\end{abstract}

Kata Kunci: Rantai, Sproket, Panas, Temperatur, Konduksi.

\section{PENDAHULUAN}

Sepeda motor merupakan alat transportasi beroda dua pada umumnya yang paling banyak digunakan saat-saat ini diseluruh negara khususnya di Indonesia, karena selain harga dan biaya bahan bakarnya yang murah juga sepeda motor merupakan jenis transportasi yang sederhana karena bisa melalui jalanjalan yang sempit dan bisa menyusup diantara kemacetan dibandingkan kendaraan roda em- pat pada umumnya, populasi jumlah pengguna sepeda motor yang beredar dijalanan Indonesia untuk tahun 2014 saja sudah mencapai 8 juta, dan kenaikan pengguna sepeda motor semakin meningkat dari tahun ke tahun.

Pada sepeda motor terdapat komponen rantai dan sproket sepeda motor pada umumnya mengalami kerusakan karena kurangnya perawatan dan pemeliharaan secara baik dan benar. Penyebabnya adalah jarang diperiksa 
kemuluran rantai setelah beberapa lama pemakaian dan kurangnya pemberian pelumas, akan tetapi temperatur yang ditimbulkan dari gesekan antara rantai dengan sproket yang dapat berpengaruh terhadap kemuluran rantai belum banyak dianalisa oleh para pakar, hal ini bisa memungkinkan terjadinya kurangnya pengetahuan kita tentang kerja rantai dan sproket sepeda motor tersebut dan tidak bisa mengembangkan prosedur-prosedur untuk perawatan rantai dan sproket sepeda motor.

Pada pengujian yang sudah dilakukan pada gear sproket sepeda motor jenis bebek, didapat bahwa umur pakai sproket rantai sepeda motor yang digunakan dalam kondisi normal sampai harus diganti adalah setelah mencapai 3.1 tahun, dan akan mengalami keausan dengan kehilangan berat sebesar 2.3\% dan mengalami perubahan dimensi dibandingkan dari kondisi baru sproket rantai tersebut. Hasil pada penelitian tersebut menghasilkan perbandingan kondisi dimensi dan berat sproket rantai baru dan lama, dan pengaruh perubahan dimensi dan berat tersebut dipengaruhi oleh gesekan dan terkikisnya antara logam sproket dan rantai yang saling bergerak. Tetapi besaran temperatur yang terjadi pada sproket rantai tidak bisa dijelaskan pengaruhnya terhadap kemuluran dan kerusakan tersebut dan hal tersebut menjadi masalah yang perlu diteliti kebenarannya.

Analisa tentang perpindahan panas dan temperatur pada sepeda motor masih banyak dilakukan pada rem sepeda motor, khususnya pada bagian kampas remnya temperatur yang dihasilkan mencapai $350 \mathrm{oC}$ dan dapat menyebabkan keausan pada kampas rem. Namun Analisa temperatur pada sproket dan rantai sepeda motor merupakan hal yang tidak bisa diabaikan.

Oleh karena itu dibutuhkan suatu metoda pengukuran yang tepat untuk mengetahui temperatur pada sproket rantai sepeda motor, agar hasil yang didapat dapat dipertanggung jawabkan dan bisa bermanfaat untuk ilmu pengetahuan. Sehingga dalam penulisan karya ilmiah ini penulis akan melakukan penelitian dan mengambil judul tentang Analisa temperatur yang timbul pada Sproket dan rantai sepeda motor saat sedang dijalankan dengan menggunakan program Nisa Heat yang berpengaruh terhadap kemuluran rantai.

Pada penelitian ini akan dianalisa temperatur yang terjadi pada sproket rantai sepeda motor, oleh karena itu berdasarkan latar belakang yang sudah ditulis di atas, penulis mengambil rumusan masalah sebagai berikut:

a. Berapakah nilai temperatur yang terjadi saat sepeda motor sedang berjalan.

b. Bagaimana hubungan antara kecepatan sepeda motor dengan kenaikan temperatur sproket rantai.

c. Bagaimana proses perpindahan panas yang terjadi pada permukaan sproket rantai dan saat temperatur lingkungan berubah-ubah.

d. Bagaimana pengaruh temperatur pada gear sproket terhadap kemuluran rantai.

Agar dapat terpenuhinya hasil penelitian ini dan didapat cakupan penelitian yang jelas, maka penulis membuat batasan penelitian yang dapat mendeskripsikan metoda penelitian ini dalam syarat-syarat tertentu dan tidak meluasnya pembahasan penelitian ini, sebagai berikut:

a. Pengukuran temperatur dilakukan pada saat sepeda motor melaju dengan kecepatan antara 40 sampai dengan $80 \mathrm{~km} / \mathrm{jam}$.

b. Material Komponen sproket termasuk ke dalam baja karbon medium, sesuai dengan AISI 1040.

c. Pengukuran dilakukan pada kondisi sproket rantai yang sudah terlumasi.

Adapun tujuan dari penelitian ini adalah sebagai berikut:

a. Mengetahui temperatur maksimal yang terjadi pada sproket rantai sepeda motor.

b. Mengetahui pengaruh yang terjadi dari temperatur terhadap kerja dan umur sproket rantai sepeda motor.

Roller chain (rantai) merupakan komponen mesin yang digunakan untuk meneruskan power (daya) dari mesin melalui perputaran sproket pada saat yang sama. Rantai mengait pada gigi sproket dan meneruskan daya tanpa slip, jadi menjamin putaran daya yang tetap.

Rantai yang terdiri dari sejumlah link kaku yang berengsel dan di sambung oleh pin untuk memberikan fleksibilitas yang diperlukan. Pada gambar 1.1 adalah nama-nama 
bagian dari rantai.

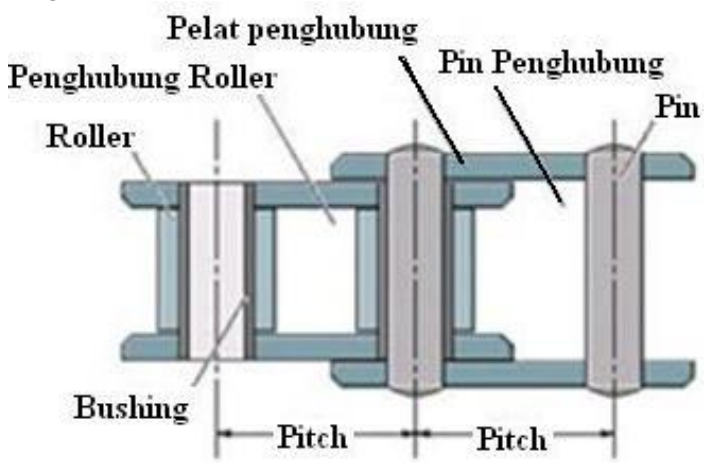

Gambar 2.1. Bagian-bagian rantai.

Rantai digunakan untuk mentransmisikan daya dimana jarak kedua poros besar dan dikehendaki tidak terjadi slip. Dibandingkan dengan transmisi roda gigi, rantai jauh lebih murah akan tetapi brisik serta kapasitas daya dan kecepatannya lebih kecil.

Rantai sebagian besar digunakan untuk mengirimkan gerakan dan daya dari satu poros ke poros yang lain, seperti ketika jarak pusat antara poros pendek seperti pada sepeda, sepeda motor, mesin pertanian, konveyor, dll dan juga rantai mungkin dapat juga digunakan untuk jarak pusat yang panjang (sampai 8 meter). Pemasangan rantai dan sproket dapat dilihat seperti pada gambar 2.2.

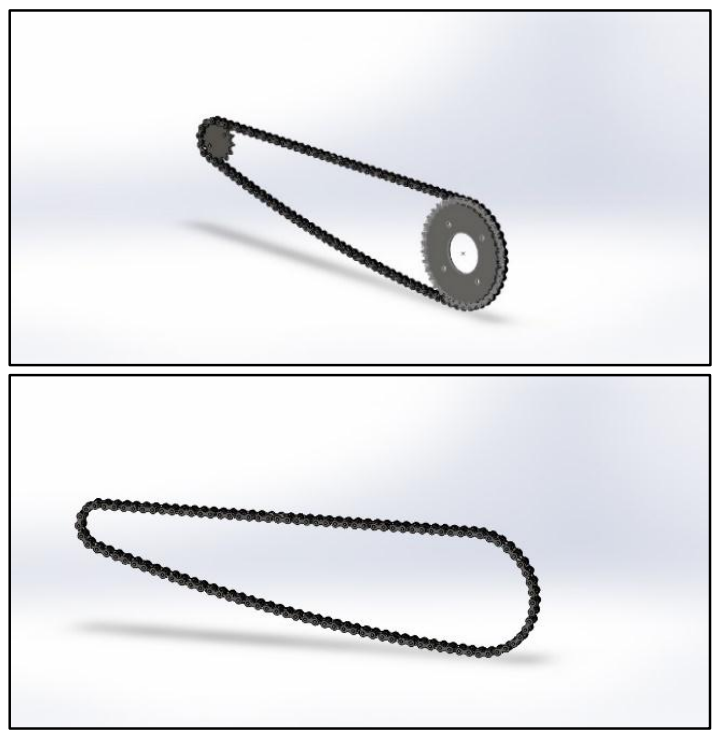

Gambar 2.2. Pemasangan rantai dan sproket

Sproket adalah roda bergerigi yang berpasangan dengan rantai, track, atau benda panjang yang bergerigi lainnya. Sproket berbeda dengan roda gigi; sproket tidak pernah bersinggungan dengan sproket lainnya dan tidak pernah cocok. Sproket juga berbeda dengan puli di mana sproket memiliki gigi sedangkan puli pada umumnya tidak memiliki gigi.

\section{a. Hubungan Antara Pitch (p) dan Pitch \\ Circle Diameter (D)}

Sebuah rantai mempunyai hubungan Pitch dan Pitch circle diameter, Pertimbangkan satu pitch $\mathrm{AB}$ dari rantai membentuk sudut $\theta$ di pusat sproket (atau lingkaran pitch), Jika $\quad \mathrm{D}=$ diameter lingkaran pitch

$\mathrm{T}=$ Jumlah gigi sprocket

Diameter sprocket luar (Do), dapat dicari dengan:

Dimana:

$$
D_{o}=D+0.8 d_{1}
$$

$\mathrm{d}_{1}=$ diameter of the chain roller

Rasio Kecepatan

Kecepatan rasio rantai diberikan oleh: $V \cdot R=\frac{N_{1}}{N_{2}}=\frac{T_{2}}{T_{1}}$

Dimana:

$\mathrm{N}_{1}=$ Kecepatan putaran sproket kecil (rpm),

$\mathrm{N}_{2}=$ Kecepatan putaran roda gigi yang lebih besar (rpm),

$\mathrm{T}_{1}=$ Jumlah gigi pada sproket kecil, dan

$\mathrm{T}_{2}=$ Jumlah gigi pada sproket yang lebih besar

Kecepatan rata-rata rantai adalah:

$v=\frac{\pi D N}{60}=\frac{T p N}{60}$

Dimana,

$\mathrm{D}=$ Diameter Pitch Circle dari sproket (meter)

$\mathrm{p}=$ Pitch dari rantai (meter)

\section{b. Perpindahan Panas}

Panas telah diketahui dapat berpindah dari tempat dengan temperatur lebih tinggi ke tempat dengan tempeatur lebih rendah. Hukum percampuran panas juga terjadi karena panas itu berpindah, sedangkan pada kalorimeter, perpindahan panas dapat terjadi dalam bentuk pertukaran panas dengan luar sistem

Secara ringkas cara perpindahan panas dapat dilakukan melalui tiga cara diantaranya konduksi, konveksi, dan radiasi.

\section{1) Perpindahan Kalor Konduksi}

Konduksi termal adalah pertukaran mikroskopis langsung dari energi kinetik partikel melalui batas antara dua sistem. Ketika 
suatu objek memiliki temperatur yang berbeda dari benda atau lingkungan di sekitarnya, panas mengalir sehingga keduanya memiliki temperatur yang sama pada suatu titik kesetimbangan termal. Perpindahan panas secara spontan terjadi dari tempat bertemperatur tinggi ke tempat bertemperatur rendah, seperti yang dijelaskan oleh hukum kedua termodinamika.

Jika ada perbedaan temperatur pada suatu benda, maka akan ada perpindahan energi dari suhu tinggi ke suhu rendah, perpindahan energi ini disebut konduksi. Laju perpindahan kalor konduksi:

Dimana:

$$
q=k A \frac{T_{2}-T_{1}}{d}
$$

$\mathrm{q} \quad=$ laju perpindahan kalor, watt

$\mathrm{T}_{2}-\mathrm{T}_{1}=$ Perbedaan temperatur antara temperatur panas $\left(\mathrm{T}_{2}\right)$ dan dingin $\left(\mathrm{T}_{1}\right)$

$\mathrm{K}=$ konduktivitas termal bahan, watt $/ \mathrm{m} .{ }^{\circ} \mathrm{K}$

A $=$ Luas permukaan $\left(\mathrm{m}^{2}\right)$

Tanda negatif pada persamaan diatas diberikan supaya memenuhi hukum termodinamika yaitu kalor mesti mengalir ke suhu yang lebih rendah.

\section{2) Perpindahan Kalor Konveksi}

Konveksi terjadi ketika aliran bahan curah atau fluida (gas atau cairan) membawa panas bersama dengan aliran materi. Aliran fluida dapat terjadi karena proses eksternal, seperti gravitasi atau gaya apung akibat energi panas mengembangkan volume fluida. Konveksi paksa terjadi ketika fluida dipaksa mengalir menggunakan pompa, kipas, atau cara mekanis lainnya.

Efek keseluruhan konveksi, dirumuskan dengan Hukum Newton tentang pendinginan: $\mathrm{q}=\mathrm{hA}(\mathrm{Tw}-\mathrm{T} \infty)$.

\section{3) Program Software Nisa/Heat}

NISA/HEAT adalah program elemen hingga untuk tujuan umum untuk menganalisis spektrum yang luas dari masalah yang dihadapi dalam transfer panas.

NISA / HEAT digunakan secara luas dalam memperkirakan distribusi temperatur, fluks panas, aliran panas, dll dalam kondisi stabil dan sementara di bawah pengaruh perpindahan panas secara konduksi/konveksi/radiasi.

\section{METODE PENELITIAN}

\section{a. Alur Penelitian}

Metodologi merupakan kerangka dasar dari tahapan penyelesaian karya ilmiah. Metodologi penulisan pada laporan penelitian ini mencakup semua kegiatan yang dilaksanakan untuk memecahkan masalah atau melakukan proses analisa terhadap permasalahan.

Oleh karena itu flow chart atau alur dari penelitian ini adalah sebagai berikut:
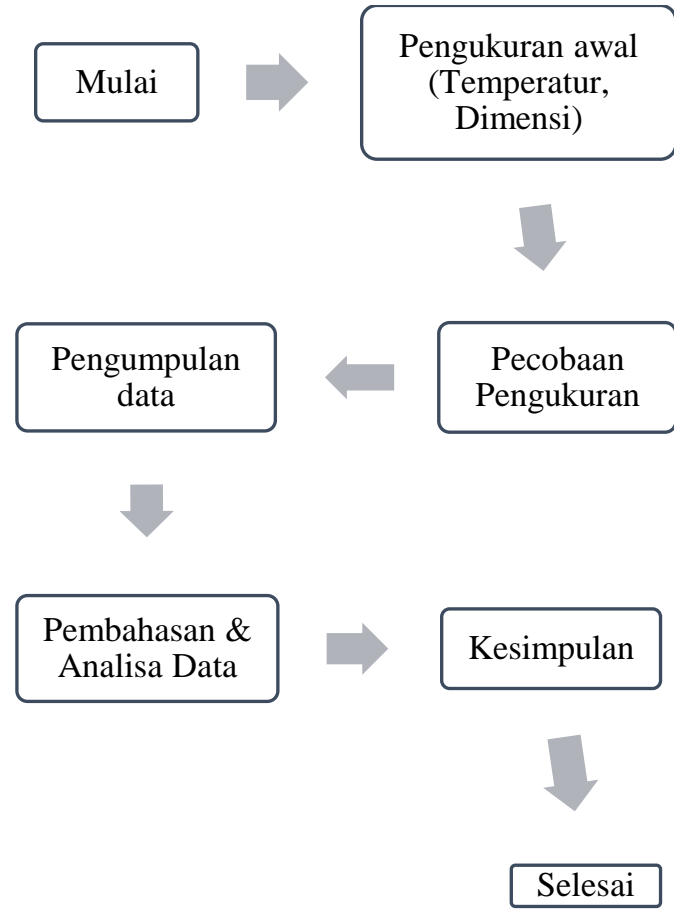

Gambar 2.3. Flow chart penelitian

\section{b. Pengukuran Geometri Rantai dan Sprocket}

Sproket terdiri dari sprocket penggerak (gear drive) dan sproket yang digerakan (gear driven), perhitungan diameter sproket didapat dari rumus-rumus yang dituliskan di tinjauan pustaka, sebagai berikut:

$\mathrm{T}_{1}=$ Jumlah gigi gear drive $=14$

$\mathrm{T}_{2}=$ Jumlah gigi gear driven $=37$

Jika diameter pitch $\mathrm{D}_{1} \& \mathrm{D}_{2}$ diketahui Nilai teoritis diameter luar sprocket (Do) adalah:

$\mathrm{Do}_{1}=54.8+0.8(7.8 \mathrm{~mm})=61.04 \mathrm{~mm}$ dan

$\mathrm{Do}_{2}=148.15+0.8(7.8 \mathrm{~mm})=154.39 \mathrm{~mm}$

Kemudian rasio kecepatan rantai didapat dari perhitungan sebagai berikut:

$$
V \cdot R=\frac{T_{2}}{T_{1}}=\frac{37}{14}=2.643
$$


Dan jika rantai berputar pada kecepatan linier $70 \mathrm{~km} / \mathrm{jam}$ maka nilai putaran sproket setelah dikonversi adalah sebesar 640 RPM, maka nilai kecepatan rata-rata rantai adalah: $v=\frac{\pi D N}{60}=\frac{\pi \times 0.154 \times 640}{60}=5.171 \mathrm{~mm} / \mathrm{sec}$

Alat-alat penelitian:

Beberapa alat yang digunakan dalam penelitian ini antara lain:

1. Alat uji pengukur temperatur panas (Thermogun)

2. Jangka Sorong

3. Penggaris

4. Stop Watch

5. Tachometer

Dari hasil pengukuran didapat beberapa nilai geometri dari rantai dan sprocket:

Tabel 1 Dimensi sproket drive

\begin{tabular}{|c|c|c|c|}
\hline Simbol & Deskripsi & Ukuran & Unit \\
\hline Do & Diameter luar & 61.35 & $\mathrm{~mm}$ \\
\hline Di & Diameter dalam & N/A & $\mathrm{mm}$ \\
\hline Dp & Diameter Pitch & 54.8 & $\mathrm{~mm}$ \\
\hline $\mathrm{p}$ & Panjang pitch & 9 & $\mathrm{~mm}$ \\
\hline $\mathrm{c}$ & $\begin{array}{c}\text { Jarak antar } \\
\text { sprocket }\end{array}$ & 50 & $\mathrm{~mm}$ \\
\hline & $\begin{array}{c}\text { Jumlah gigi } \\
\text { Sprocket 1 } \\
\text { (Diive) }\end{array}$ & 14 & N/A \\
$\mathrm{N}_{1}$ & Din \\
\hline
\end{tabular}

\begin{tabular}{|c|c|l|c|}
\hline Simbol & Deskripsi & Ukuran & Unit \\
\hline a & Lebar muka gigi & 2.3 & $\mathrm{~mm}$ \\
\hline b & Jarak antar gigi & 10.065 & $\mathrm{~mm}$ \\
\hline c & Tebal gigi & 3.5 & $\mathrm{~mm}$ \\
\hline $\mathrm{d}$ & Tinggi gigi & 5.6 & $\mathrm{~mm}$ \\
\hline
\end{tabular}

Tabel 2 Dimensi Sproket driven

\begin{tabular}{|c|c|c|c|}
\hline Simbol & Deskripsi & Ukuran & Unit \\
\hline Do & Diameter luar & 154.5 & $\mathrm{~mm}$ \\
\hline $\mathrm{Di}$ & Diameter dalam & 58.45 & $\mathrm{~mm}$ \\
\hline $\mathrm{Dp}$ & Diameter Pitch & 148.15 & $\mathrm{~mm}$ \\
\hline $\mathrm{p}$ & Panjang pitch & 9 & $\mathrm{~mm}$ \\
\hline $\mathrm{c}$ & $\begin{array}{c}\text { Jarak antar } \\
\text { sprocket }\end{array}$ & 50 & $\mathrm{~mm}$ \\
\hline & $\begin{array}{c}\text { Jumlah gigi } \\
\text { Sprocket 2 } \\
\text { (Driven) }\end{array}$ & 37 & $\mathrm{~N} / \mathrm{A}$ \\
\hline
\end{tabular}

\begin{tabular}{|c|c|l|l|}
\hline Simbol & Deskripsi & Ukuran & Unit \\
\hline $\mathrm{a}$ & Lebar muka gigi & 2.15 & $\mathrm{~mm}$ \\
\hline $\mathrm{b}$ & Jarak antar gigi & 10.85 & $\mathrm{~mm}$ \\
\hline $\mathrm{c}$ & Tebal gigi & 3.85 & $\mathrm{~mm}$ \\
\hline $\mathrm{d}$ & Tinggi gigi & 6.8 & $\mathrm{~mm}$ \\
\hline
\end{tabular}

Tabel 3 Dimensi rantai

\begin{tabular}{|c|c|c|c|}
\hline Simbol & Deskripsi & Ukuran & Unit \\
\hline $\mathrm{P}$ & $\begin{array}{c}\text { Pitch, jarak antar } \\
\text { roller }\end{array}$ & 12.2 & $\mathrm{~mm}$ \\
\hline $\mathrm{D}_{\text {pin }}$ & Diameter pin & 3.9 & $\mathrm{~mm}$ \\
\hline $\mathrm{D}_{\mathrm{R}}$ & Diameter Roller & 7.8 & $\mathrm{~mm}$ \\
\hline $\mathrm{b}$ & Lebar Roller & 6.4 & $\mathrm{~mm}$ \\
\hline $\mathrm{L}$ & Panjang rantai & 1320.8 & $\mathrm{~mm}$ \\
\hline
\end{tabular}

Prosedur penelitian yang dilakukan antara lain:

1) Pencatatan temperatur pada gear dan sproket sebelum sepeda motor di jalankan dan pengukuran lebar gigi pada gear sproket.

2) Roda gigi dipasang pada roda sepeda motor

3) Motor dijalankan hingga kecepatan mulai 50 sampai dengan $70 \mathrm{~km} / \mathrm{jam}$ selama 30 menit

4) Sepeda motor dihentikan dan dilakukan pengukuran temperatur dengan menggunakan Thermogun pada roda gigi dan sproket.

5) Diukur panjang pelat pada sambungan rantai dengan menggunakan kaliper.

6) Lakukan langkah $3 \mathrm{~s} / \mathrm{d} 5$ hingga 10 kali.

7) Lakukan pencatatan sebanyak 10 kali.

Didapat beberapa hasil Tabel 4 . Pencatatan temperatur pada gear drive, driven dan rantai

\begin{tabular}{|c|c|c|c|c|c|}
\hline No. & $\begin{array}{c}\text { Speed } \\
(\mathbf{k m} / \mathbf{h})\end{array}$ & $\begin{array}{c}\text { T gear } \\
\text { Drive } \\
\left({ }^{\circ} \mathrm{C}\right)\end{array}$ & $\begin{array}{c}\text { T gear } \\
\text { Driven } \\
\left({ }^{\circ} \mathrm{C}\right)\end{array}$ & $\begin{array}{c}\text { T Chain } \\
\left({ }^{\circ} \mathrm{C}\right)\end{array}$ & $\begin{array}{c}\text { T Room } \\
\left({ }^{\circ} \mathbf{C}\right)\end{array}$ \\
\hline 1 & 40 & 39.2 & 39.2 & 37.6 & 36.3 \\
\hline 2 & 40 & 39.7 & 39.7 & 38.5 & 36.7 \\
\hline 3 & 40 & 39.5 & 39.5 & 38.2 & 36.4 \\
\hline 4 & 40 & 40.5 & 40.5 & 38.7 & 37.5 \\
\hline 5 & 40 & 40.3 & 40.3 & 38.6 & 37.4 \\
\hline 6 & 40 & 40.9 & 40.9 & 38.8 & 37.6 \\
\hline 7 & 40 & 39.8 & 39.8 & 38.1 & 36.8 \\
\hline 8 & 40 & 41.5 & 41.5 & 38.4 & 37.1 \\
\hline 9 & 40 & 38.5 & 38.5 & 36.3 & 35.2 \\
\hline 10 & 40 & 38.8 & 38.8 & 36.1 & 35.6 \\
\hline $\begin{array}{c}\text { Rata } \\
\text { rata }\end{array}$ & & 39.87 & 39.87 & 37.93 & 36.66 \\
\hline
\end{tabular}




\begin{tabular}{|c|c|c|c|c|c|}
\hline No. & $\begin{array}{c}\text { Speed } \\
(\mathbf{k m} / \mathbf{h})\end{array}$ & $\begin{array}{c}\text { T gear } \\
\text { Drive } \\
\left({ }^{\circ} \mathbf{C}\right)\end{array}$ & $\begin{array}{c}\text { T gear } \\
\text { Driven } \\
\left({ }^{\circ} \mathbf{C}\right)\end{array}$ & $\begin{array}{c}\text { T Chain } \\
\left({ }^{\circ} \mathbf{C}\right)\end{array}$ & $\begin{array}{c}\text { T Room } \\
\left({ }^{\circ} \mathbf{C}\right)\end{array}$ \\
\hline 1 & 50 & 43.4 & 43.4 & 40.6 & 37.8 \\
\hline 2 & 50 & 44.7 & 44.7 & 41.2 & 38.4 \\
\hline 3 & 50 & 45.4 & 45.4 & 41.8 & 38.6 \\
\hline 4 & 50 & 43.2 & 43.2 & 40.3 & 37.3 \\
\hline 5 & 50 & 40.6 & 40.6 & 37.5 & 34.2 \\
\hline 6 & 50 & 45.4 & 45.4 & 41.7 & 38.9 \\
\hline 7 & 50 & 45.3 & 45.3 & 41.1 & 38.5 \\
\hline 8 & 50 & 45.5 & 45.5 & 41.2 & 38.4 \\
\hline 9 & 50 & 43.5 & 43.5 & 40.5 & 37.6 \\
\hline 10 & 50 & 43.6 & 43.6 & 40.5 & 37.5 \\
\hline $\begin{array}{c}\text { Rata } \\
\text { rata }\end{array}$ & & 44.06 & 44.06 & 40.64 & 37.72 \\
\hline
\end{tabular}

\begin{tabular}{|c|c|c|c|c|c|}
\hline No. & $\begin{array}{c}\text { Speed } \\
(\mathbf{k m} / \mathbf{h})\end{array}$ & $\begin{array}{c}\text { T gear } \\
\text { Drive } \\
\left({ }^{\circ} \mathbf{C}\right)\end{array}$ & $\begin{array}{c}\text { T gear } \\
\text { Driven } \\
\left({ }^{\circ} \mathbf{C}\right)\end{array}$ & $\begin{array}{c}\mathbf{T} \\
\text { Chain } \\
\left({ }^{\circ} \mathbf{C}\right)\end{array}$ & $\begin{array}{c}\mathbf{T} \\
\text { Room } \\
\left({ }^{\circ} \mathbf{C}\right)\end{array}$ \\
\hline 1 & 60 & 48.2 & 48.2 & 43.5 & 37.6 \\
\hline 2 & 60 & 47.4 & 47.4 & 42.1 & 35.6 \\
\hline 3 & 60 & 46.6 & 46.6 & 41.5 & 35.1 \\
\hline 4 & 60 & 46.1 & 46.1 & 41.6 & 34.9 \\
\hline 5 & 60 & 46.5 & 46.5 & 41.5 & 35 \\
\hline 6 & 60 & 48 & 48 & 43.3 & 37.6 \\
\hline 7 & 60 & 47.3 & 47.3 & 45.4 & 37.3 \\
\hline 8 & 60 & 48.1 & 48.1 & 44.2 & 38 \\
\hline 9 & 60 & 49.7 & 49.7 & 44.3 & 38.8 \\
\hline 10 & 60 & 48.3 & 48.3 & 44 & 38 \\
\hline $\begin{array}{c}\text { Rata } \\
\text { rata }\end{array}$ & & 47.62 & 47.62 & 43.14 & 36.79 \\
\hline
\end{tabular}

\begin{tabular}{|c|c|c|c|c|c|}
\hline No. & $\begin{array}{c}\text { Speed } \\
(\mathbf{k m} / \mathbf{h})\end{array}$ & $\begin{array}{c}\text { T gear } \\
\text { Drive } \\
\left({ }^{\circ} \mathbf{C}\right)\end{array}$ & $\begin{array}{c}\text { T gear } \\
\text { Driven } \\
\left({ }^{\circ} \mathbf{C}\right)\end{array}$ & $\begin{array}{c}\mathrm{T} \\
\text { Chain } \\
\left({ }^{\circ} \mathbf{C}\right)\end{array}$ & $\begin{array}{c}\mathrm{T} \\
\text { Room } \\
\left({ }^{\circ} \mathbf{C}\right)\end{array}$ \\
\hline 1 & 70 & 50.3 & 50.3 & 45.1 & 35.8 \\
\hline 2 & 70 & 50.8 & 50.8 & 45.9 & 37.4 \\
\hline 3 & 70 & 52 & 52 & 46.5 & 37.6 \\
\hline 4 & 70 & 52.3 & 52.3 & 47 & 38 \\
\hline 5 & 70 & 50.5 & 50.5 & 45.7 & 37 \\
\hline 6 & 70 & 50.1 & 50.1 & 44.8 & 36.1 \\
\hline 7 & 70 & 52.1 & 52.1 & 46.8 & 37.6 \\
\hline 8 & 70 & 51.7 & 51.7 & 46.1 & 37.5 \\
\hline 9 & 70 & 52.1 & 52.1 & 46.8 & 37.5 \\
\hline 10 & 70 & 50.4 & 50.4 & 45.5 & 36.5 \\
\hline
\end{tabular}

Perhitungan nilai perpindahan panas berdarsarkan rumus di atas adalah:

$q=k A \frac{T_{2}-T_{1}}{d}$

$q=38 \times 0.000353 \times \frac{52-38}{0.035}$

$$
=0.543 \mathrm{Watt}
$$

Dimana:

$\mathrm{K}=$ konduktivitas thermal Cast Alloy steel $=$ $38 \mathrm{~W} /\left(\mathrm{m}^{\circ} \mathrm{K}\right)$

$\mathrm{A}=$ Luas permukaan gigi pada sprocket $=$ $0.0000357 \mathrm{~m}^{2}$

$\mathrm{T}_{2}=$ Temperatur beban pada gigi $=52^{\circ} \mathrm{C}$

$\mathrm{T}_{1}=$ Temperatur udara $=38^{\circ} \mathrm{C}$

\section{c. Uji Validitas data penelitian}

Uji Validitas dilakukan pada semua tingkat kecepatan dan semua temperatur dengan tingkat signifikansi 5\%. Jika $r$ hitung $\geq \mathrm{r}$ tabel (uji 2 sisi dengan sig. 0,05) maka instrumen atau item-item pertanyaan berkorelasi signifikan terhadap skor total (dinyatakan valid).

Hipotesis penelitian yang diambil adalah sebagai berikut:

$\mathrm{H}_{\mathrm{o}}=$ Tidak adanya pengaruh yang signifikan antar variabel temperatur pada komponen dan material komponen, jika nilai sig. (2-tailed) < 0.05 , maka Ho diterima

$\mathrm{H}_{1}=$ Adanya pengaruh yang signifikan antar variabel temperatur pada komponen dan material komponen, jika nilai sig. $(2$ tailed $)>0.05$, maka Ho ditolak.

Nilai $r$ hitung yang didapat dari perhitungan di SPSS adalah sebagai berikut:

Tabel 5 Nilai $r$ hitung pada masing-masing temperatur komponen

\begin{tabular}{|l|c|c|c|c|}
\hline \multirow{2}{*}{ Nilai r hitumg } & \multicolumn{4}{|c|}{ Speed } \\
\cline { 2 - 5 } & $40 \mathrm{~km} / \mathrm{h}$ & $50 \mathrm{~km} / \mathbf{h}$ & $60 \mathrm{~km} / \mathbf{h}$ & $70 \mathbf{~ m m} / \mathbf{h}$ \\
\hline r TGearDrive & 0.965 & 0.991 & 0.946 & 0.987 \\
\hline r TGearDriven & 0.965 & 0.991 & 0.946 & 0.987 \\
\hline r TChain & 0.927 & 0.984 & 0.881 & 0.985 \\
\hline r TRoom & 0.965 & 0.985 & 0.99 & 0.94 \\
\hline
\end{tabular}

Maka karena semua nilai $r$ hitung adalah $>\mathrm{r}$ tabel $=0.6319$, maka data tersebut valid dan mempunyai korelasi antar masing-masing variabel.

\section{d. Uji Reliabilitas Data Penelitian}

Setelah data diolah dengan menggunakan uji reliabilitas di software SPSS, maka hasil uji reliabilitas dapat dilihat pada lampiran 8, Berikut interpretasi hasil uji reliabilitas dengan menggunakan metode Alpha Cronbach:

$>$ Speed $40 \mathrm{~km} / \mathrm{h}=0.851$, maka reliabilitas tinggi

$>$ Speed $50 \mathrm{~km} / \mathrm{h}=0.857$, maka reliabilitas tinggi

> Speed $60 \mathrm{~km} / \mathrm{h}=0.847$, maka reliabilitas tinggi

> Speed $70 \mathrm{~km} / \mathrm{h}=0.855$, maka reliabilitas tinggi

Oleh karena itu dapat disimpulkan bahwa instrumen-instrumen yang digunakan untuk mengukur variabel temperatur dapat dikatakan reliabel atau handal. 


\section{e. Uji Anova}

Uji Anova satu faktor bertujuan untuk membandingkan nilai rata-rata yang terdapat pada variabel terikat di semua kelompok yang dibandingkan.

Output 1

Pada tabel Test of Homogeneity of Variances kita lihat nilai signifikansi (sig.) kemudian kita bandingkan dengan nilai 0.05 , jika nilai sig. $>0.05$ maka data tersebut homogen.

$>$ Pada speed $40 \mathrm{~km} / \mathrm{h}$, nilai sig. $=0.998>$ 0.05 , maka data sudah homogen

$>$ Pada speed $50 \mathrm{~km} / \mathrm{h}$, nilai sig. $=0.452>$ 0.05 , maka data sudah homogen

$>$ Pada speed $60 \mathrm{~km} / \mathrm{h}$, nilai sig. $=0.383>$ 0.05 , maka data sudah homogen

$>$ Pada speed $70 \mathrm{~km} / \mathrm{h}$, nilai sig. $=0.248>$ 0.05 , maka data sudah homogen

\section{Output 2}

Pada output 3 kita melihat hasil hipotesis yang sebelumnya sudah kita sebutkan di bagian uji validitas, Untuk menarik kesimpulan kita memerlukan nilai distribusi $\mathrm{F}$ (nilai $\mathrm{F}$ tabel) dengan ketentuan:

$>$ Taraf signifikansi 0,05

$>$ df Between Groups $=$ jumlah variabel -1 $=3-1=2$

$>$ df Within groups $=$ jumlah data - jumlah variabel $=30-3=27$

Maka tiap-tiap kecepatan/speed kesimpulan hipotesis adalah:

1) Speed $40 \mathrm{~km} / \mathrm{h}, \mathrm{F}$ hitung $=13.858$, karena $13.858>3,35$ maka Ho ditolak

2) Speed $50 \mathrm{~km} / \mathrm{h}, \mathrm{F}$ hitung $=18.834$, karena $18.834<3,35$ maka Ho ditolak

3) Speed $60 \mathrm{~km} / \mathrm{h}, \mathrm{F}$ hitung $=47.766$, karena $47.766<3,35$ maka Ho ditolak

4) Speed $70 \mathrm{~km} / \mathrm{h}, \mathrm{F}$ hitung $=127.38$, karena $127.38>3,35$ maka Ho ditolak

Maka dari ke-empat hasil hipotesis diatas, karena Ho ditolak maka dapat disimpulkan bahwa adanya pengaruh yang signifikan antara temperatur yang dihasilkan dengan komponen rantai-sproket.

Kemudian analisis temperatur dilakukan dengan mengambil sampel pada temperatur udara tertinggi dan temperatur rantai-sproket tertinggi, kemudian dicari analisa distribusi temperatur dengan menggunakan software NISA Heat. Berikut adalah data-data untuk analisa distribusi temperatur:

Tabel 6 Data material dan temperatur yang dianalisa

\begin{tabular}{|l|c|c|c|c|c|c|}
\hline $\begin{array}{c}\text { Bagian } \\
\text { Komponen }\end{array}$ & \multicolumn{2}{|c|}{ Gear Drive } & \multicolumn{2}{c|}{ Gear Driven } & \multicolumn{2}{c|}{$\begin{array}{c}\text { Chain } \\
\text { Assembly }\end{array}$} \\
\hline \multicolumn{1}{|c|}{ Deskripsi } & Nilai & Satuan & Nilai & Satuan & Nilai & Satuan \\
\hline $\begin{array}{l}\text { Temperatur } \\
\text { udara Max. }\end{array}$ & 38 & ${ }^{\circ} \mathrm{C}$ & 38 & ${ }^{\circ} \mathrm{C}$ & 38 & ${ }^{\circ} \mathrm{C}$ \\
\hline $\begin{array}{l}\text { Temp. Max } \\
\text { gear drive }\end{array}$ & 52,3 & ${ }^{\circ} \mathrm{C}$ & 52,3 & ${ }^{\circ} \mathrm{C}$ & 47 & ${ }^{\circ} \mathrm{C}$ \\
\hline $\begin{array}{l}\text { Koefisien } \\
\text { konveksi } \\
\text { udara }\end{array}$ & 75 & $\begin{array}{c}\mathrm{W} / \\
\left(\mathrm{m}^{2} \mathrm{~K}\right)\end{array}$ & 75 & $\begin{array}{c}\mathrm{W} / \\
\left(\mathrm{m}^{2} \mathrm{~K}\right)\end{array}$ & 75 & $\begin{array}{c}\mathrm{W} / \\
\left(\mathrm{m}^{2} \mathrm{~K}\right)\end{array}$ \\
\hline $\begin{array}{l}\text { Material gear } \\
\text { driven }\end{array}$ & \multicolumn{2}{|c|}{ AISI $1045 \mathrm{steel}$} & \multicolumn{2}{|c|}{ Cast alloy steel } & \multicolumn{2}{c|}{ Cast alloy steel } \\
\hline $\begin{array}{l}\text { Konduktivitas } \\
\text { thermal }\end{array}$ & 49,8 & $\begin{array}{c}\mathrm{W} / \\
(\mathrm{mK})\end{array}$ & 38 & $\begin{array}{c}\mathrm{W} / \\
(\mathrm{mK})\end{array}$ & 38 & $\begin{array}{c}\mathrm{W} / \\
(\mathrm{mK})\end{array}$ \\
\hline
\end{tabular}

\section{HASIL DAN PEMBAHASAN}

Hasil interpretasi distribusi temperatur dapat dilihat pada gambar analisis dengan software Nisa heat sebagai berikut:

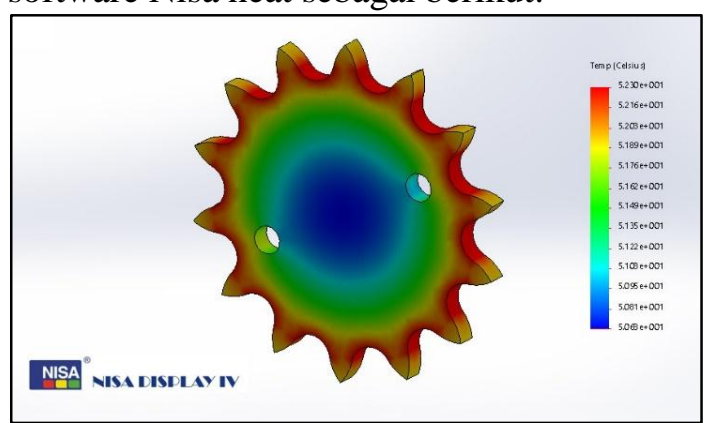

Gambar 4.1 Distribusi temperatur pada gear drive.

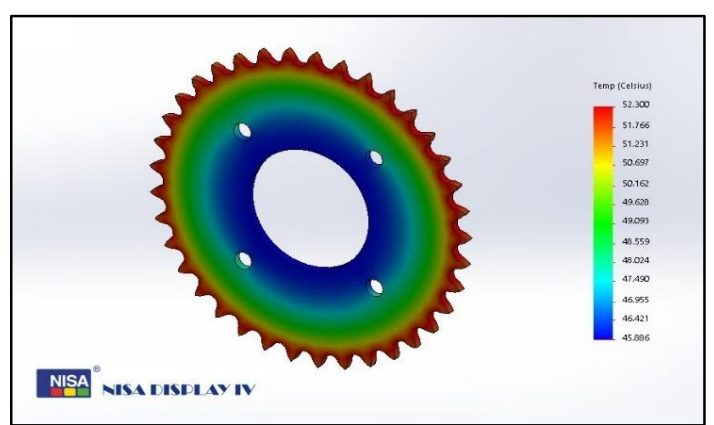

Gambar 4.2 Distribusi temperatur pada gear driven.

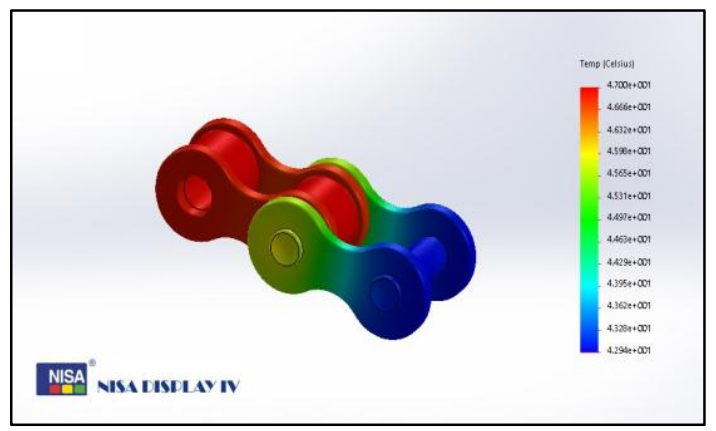

Gambar 4.3 Distribusi temperatur pada rantai

Terlihat pada distribusi temperatur di sproket, bagian yang berwarna biru dari rantai drive dibandingkan dengan rantai driven mempunyai nilai yang berbeda. Titik temperatur terendah dari sproket drive adalah 
$50.68^{\circ} \mathrm{C}$ sedangkan titik temperatur terendah dari sproket driven adalah $45.8^{\circ} \mathrm{C}$ karena nilai konduktivitas material yang dimiliki oleh kedua sproket tersebut yang berbeda.

Pembebanan awal pada rantai dilakukan pertama kali pada bagian rol, karena rol tersebut bersentuhan langsung dengan sproket, sehingga pada permukaan rol tersebut merupakan titik temperatur tertinggi dari rantai.

\section{Pengaruh Temperatur terhadap kemuluran rantai}

Pada proses kemuluran rantai dipengaruhi oleh beberapa faktor, beberapa diantaranya adalah tegangan pada rantai dan temperatur. Sebelumnya telah dihitung panjang rantai awal sebelum pemakaian adalah sebesar $1320.8 \mathrm{~mm}$, kemudian sesudah rantai digunakan dalam jangka waktu tertentu rantai mengalami kemuluran sebesar $0.78 \%$ atau mengalami kemuluran sepanjang 1331.08 $\mathrm{mm}$, dimana selisih sesudah mulur dan sebelum mulur adalah sebesar $10.28 \mathrm{~mm}$ setelah pemakaian selama 6 bulan, dimana perharinya sepeda motor digunakan selama rata-rata 12 jam. rantai:

Berikut adalah perhitungan kemuluran

1. Panjang awal $=1320.8 \mathrm{~mm}$

2. Panjang akhir $=1331.08 \mathrm{~mm}$

3. Panjang mulur $=10.28 \mathrm{~mm}$

\section{KESIMPULAN}

Dari hasil dapat diketahui bahwa berdasarkan pada pemusatan beban temperatur yang terjadi adalah:

1. Pada Gear drive dan driven beban temperatur terbesar berada pada pertengahan gigi-gigi, yaitu pada lingkaran pitch, karena pada sisi tersebut kontak langsung dengan roller rantai.

2. Pada rantai beban temperatur terbesar pada roller rantai yang berwarna merah, dan distribusi temperatur terendah pada bagian rantai yang lebih jauh dari roller yaitu pada pertengahan link rantai.

3. Nilai perpindahan panas (heat transfer) yang terjadi adalah $0.543 \mathrm{Watt}$

\section{DAFTAR PUSTAKA}

Achmad Z (1999). Elemen Mesin I. Bandung: Refika Aditama

Abrianto Akuan, ST., MT (2013). Analisis Keausan Sproket Rantai Pada Sepeda Motor. Jurusan Teknik Metalurgi FTUNJANI.

Daswin Basselo, Stenly Tangkuman, Michael Rembet (2015). Optimasi Diameter Poros Terhadap Variasi Diameter Sproket Pada Roda Belakang Sepeda Motor. Jurnal Online Poros Teknik Mesin Volume 3 Nomor 1.

Ebhota Williams S, Ademola Emmanuel, Oghenekaro Peter (April 2014). Fundamentals of Sprocket Design and Reverse Engineering of Rear Sprocket of a Yamaha CY80 Motorcycle. National Engineering Design Development Institute. International Journal of Engineering and Technology Volume 4 No. 4.

Mott. R. L (2009). Elemen-Elemen Mesin Dalam Perancangan Mekanis. Yogyakarta: ANDI

M. Bougataya, A. Lakhsasi, Y .Savaria and D. Massicotte (2002). Mixed Fluid-Heat Transfer Approach for VLSI Steady State Thermal Analysis. Proceedings of the 2002 IEEE Canadian Conference on Electrical \& Computer Engineering.

Neimann, Gustav dan H Winter (1992). Elemen Mesin. Jakarta: Erlangga.

Nikhil S. Pisal, V.J. Khot, Swapnil S. Kulkarni. Design And Development Of Motorcycle Chain Links By Using C.A.E. Software. International Journal of Scientific Research and Management Studies (IJSRMS). Volume 2 Issue 4, pg: 175-183.

Sungkono Djoko \& Feri Fatkur Rizal (2001). Perbandingan Distribusi Temperatur Pada Drum Brakes Standar dan Modifikasi. Jurnal Teknik Mesin FTIITS, Volume 1, Nomor 1. 